\title{
Analysis of nursing professional practices under the perspective of the integrality of assistance to the woman
}

\author{
Análise das práticas profissionais de enfermeiras na perspectiva da integralidade da \\ assistência à mulher
Análisis de las prácticas profesionales de enfermeras en la perspectiva de la atención integral a la mujer

Alana Gonçalves Xavier ${ }^{1}$, Sheila Milena Pessoa dos Santos ${ }^{1}$, Fernanda Laísy Pereira de Sousa ${ }^{1}$, Francicleide Luciano da Silva ${ }^{1}$, Roberta Lima Gonçalves ${ }^{1}$, Gilvânia Patrícia do Nascimento Paixão

This study aimed at reviewing the nursing professional practices under the perspective of the integrality of assistance to the woman. It is a descriptive and exploratory, qualitative study made in the county of Lagoa Seca, PB, Brazil, from October 2013 to February 2014. The techniques of participant observation, document analysis and semi-structured interviews were used. Practices of three nurses were evaluated, through interviews, analysis of medical records, observation in the waiting rooms and clinical assistance, using semi-structured script. From the technique of thematic content analysis, it was found that health promotion was contemplated only on an individual basis, the assistance is based on attendance restricted to complaints, and the care neglects various laws on health. It is considered that the professionals have the potential to develop integral assistance, however there is no commitment. The study indicates the need for changes in care practices in order to corroborate improvement concerning care.

Descriptors: Comprehensive Health Care; Women's Health; Nursing Care.

Objetivou-se analisar as práticas profissionais de enfermeiras na perspectiva da integralidade da assistência à mulher. Estudo descritivo e exploratório, qualitativo, realizado no município de Lagoa Seca, PB, Brasil, entre outubro de 2013 a fevereiro de 2014. Utilizadas as técnicas de observação participante, análise documental e entrevista semiestruturada. Avaliadas as práticas de três enfermeiras, através de entrevista, análise de prontuários, observação em sala de espera e atendimentos clínicos, utilizando-se roteiros semiestruturados. A partir da técnica da análise de conteúdo temática, verificou-se que a promoção da saúde foi contemplada apenas em caráter individual, a assistência baseia-se em atendimentos restritos às queixas, a atenção negligencia diversas legislações em saúde. Considera-se que as profissionais têm potencialidade para desenvolver cuidado integral, contudo não há comprometimento. Há necessidade de mudanças das práticas assistenciais no sentido corroborar melhorias na assistência.

Descritores: Assistência Integral à Saúde; Saúde da Mulher; Cuidados de Enfermagem.

El objetivo fue analizar las prácticas profesionales de enfermaras en la perspectiva de la atención integral a la mujer. Estudio descriptivo, exploratorio y cualitativo, realizado en Lagoa Seca, PB, Brasil, entre octubre de 2013 y febrero de 2014. Se utilizaron observación participante, análisis de documentos y entrevista semiestructurada. Evaluadas las prácticas de tres enfermeras, mediante entrevista, análisis de registros médicos, observación en la sala de espera y atención clínica, utilizándose guiones semiestructurados. A partir de la técnica de análisis de contenido temático, se constató que la promoción de la salud ha sido contemplada sólo individualmente, con atención basada en quejas, ignorada por diversas leyes de salud. Se considera que los profesionales tienen potencial para desarrollar una atención integral, pero no hay compromiso. Hay la necesidad de cambio de las prácticas de atención para corroborar mejorías en la atención.

Descriptores: Atención Integral de Salud; Salud de la Mujer; Atención de Enfermería.

\footnotetext{
${ }^{1}$ Universidade Federal de Campina Grande. Campina Grande, PB, Brazil.

${ }^{2}$ Universidade do Estado da Bahia. Juazeiro, BA, Brazil. 


\section{Introduction}

The integrality is inserted as a fundamental guideline in the Unified Health System, and it is understood as a set of notions concerning an enhanced multi-professional assistance, analyzing the human being under the bio-psychosocial focus, who has feelings, desires, afflictions and rationalities ${ }^{(1)}$.

Several population groups have questions which demand integrality as the bases for their strategies of assistance to health. For example, it is possible to mention the mental health and the health of indian populations. However, one of the themes which had higher advancement in terms of proposal to integrality was the women's health ${ }^{(2)}$. Concerning the assistance to the woman the integrality of the care is based on three aspects: public policies which assist the demands of the female population; organization of the service and practices of the health professionals ${ }^{(3)}$.

The public polices turned to the health of the woman have existed since the first decades of the $20^{\text {th }}$ century, however, they were limited to the obstetric demand, with specific interest on the child ${ }^{(4)}$. In the 70 s and the 80 s the women began to fight for their rights and with the feminist movement they made their claim visible, which could no longer be ignored ${ }^{(5)}$.

With the creation of the Unified Health System and the principles of universality, integrality of the actions, equity, decentralization of the services, from the municipalization and popular participation, the women gained voice. So, policies and programs which thoroughly approached the woman emerged $^{(6)}$. However, despite the advances observed concerning the health public policies of the woman, it is still possible to perceive the fragility in their implementation, especially, by the exclusion of some segments of women, among them, postmenopausal women, adolescents, bearers of special needs, prostitutes, lesbians, in prison or suffering violence, and the incipient attention to the aspects concerning the care related to their class, generation, ethnic group and gender.
Following the optics of enhanced assistance, the organization of the services must be articulated, raising the possibilities of effectively providing the needs of the women ${ }^{(7)}$. As part of those services as well as of a net of attention to health, the Family Health Strategy consists of a scenario which favors the implementation of this working logics, once it has the care, human and material technologies, which are necessary for the thorough attention in health.

Nursing, in this multi-professional construction of collective health, must assume its nuclei of competence and responsibility: the care. Such care has the purpose to transpose individual and collective subjectivities. Under this perspective, nursing has the captivity to go through different domains of knowledge, once, the health professional has, as focus, the person to be taken care of, so, he can establish interlocution with other agents, aiming at obtaining the necessary technology to assistance, keeping relation with the team and with the family, acting in the process of transformation of the reality ${ }^{(8)}$.

Under such perspective, the nursing appointment is understood as a private activity of the nurse, which allows the identification of problematic situations and potentialities of the patient, a scientific method is used to identify situations of health/disease, prescribe and implement nursing interventions, which contribute for the promotion, prevention, protection of health, recovery and rehabilitation of the person/family/community, besides allowing the exercising of their autonomy ${ }^{(9)}$.

The promotion of health leads to the stimulus for the adoption of healthy styles of life, actions of health developed should guarantee the implantation of public policies turned to the quality of life and to the transformation of the determinant factors of the condition of health. Among the actions of health protection, there are measures of epidemiological vigilance, immunizations and specific counselling. The health protection is provided through regular appointments and health exams, providing the knowledge of the condition of health of the person 
and the community, through the identification of risks. The actions of recovery of health, consists of healing and treatment measures, turned to the recovery of the individual health and complement the thorough attention to health ${ }^{(4)}$.

So, considering that the thorough care guides the nursing practice in the attention to the woman, the experience of the researchers in activities of teaching, research and extension in the services motivated the development of this study which had the following guiding question: Do the nursing professional practices provide an answer to the perspective of the integrality of the assistance to the woman? So, the study aimed at analyzing the nursing professional practice under the perspective of the integrality of the assistance to the woman.

The research presented relevance for dealing with questions to be learned and incorporated in the daily practices of the health professionals, especially the nurses, who in the current scenario of primary care, are responsible, together with the other health professionals, for the assistance to the woman.

\section{Method}

This is an article elaborated from a project called 'Sexual and reproductive health: a study on the integrality of the assistance from the health professional practices in the care to the woman', linked to the Institutional Program of Volunteers in Scientific Initiation, of the National Counsel of Scientific and Technological Development, term 2013-2014.

It is a descriptive, exploratory and qualitative study, developed in three Family Health Units, located in Lagoa Seca, in the countryside of State of Paraíba, Brazil, made from October, 2013 to February, 2014. Each multi-disciplinary team of Family Health consisted of only one nurse. The option for these units occurred from the participation of the health professionals as tutors in the Program of Education through the Work for Health (PET-Saúde), along the line of action called the Stork Network.
For the data collection, the techniques of participant observation called document analyses and semi-structured interviews were used. For such, semistructured scripts covering converging aspects in the three instruments concerning the health professional practices were used, which discussed the activities of counselling, health and clinic education focused on the attention to the woman.

The participant observation is the direct contact of the researcher with the object of the investigation in order to obtain information on the reality of his own context, allowing to seize different situations and problems which are not obtained through questions. In turn, the documental analysis is the examination of stable data which have not received analytical treatment. The individualized semistructured interview is characterized by the seizure of values, attitudes and opinions of the interviewees on specific questions which involve the problem under analysis $^{(10)}$. The triangulation of the data is justified, once this strategy allows the enhancing of the scope of analysis integrating different perspectives for the comprehension of the phenomenon under examination ${ }^{(11)}$.

The participants of the process of investigation were three nurses, responsible for the assistance to the health of the woman. Professional practices were evaluated, through observation in waiting rooms and clinical appointments during 12 shifts and, consequently, the analysis of medical records. From such sample, it was possible to analyze 42 appointments to the women and 96 medical records, among them the pre-natal and gynecological appointments were highlighted, once the remaining appointments were focused on the control/treatment of diseases, being away from the thorough attention to the woman. The interviews with the health professionals were recorded with a help of a portable recorder, in order to allow the literal transcript and maximize the trust in the exposure of the statements. No time limits were established for the interviews, so the length ranged from 10 to 17 minutes according to the answers offe- 
red by the participants. During the tabulation of the data and exposition of the interviewees, fictitious names were used, for the health professionals and for the Family Health Units, thus preserving anonymity and secrecy.

The following issues were excluded from the sample: appointments and medical records of subjects under 18 years of age, appointments offered by health professionals followed by graduation students, once their presence could interfere in the routine of the assistance, documents filled in by students and/or professors, as well as registers filled in by the other health professionals and as well as the ones who had not worked in the Family Health Unit during the period of the research.

For the data examination, the technique of thematic content analysis was used ${ }^{(12)}$ with carefully reading of the data collected through the participant observation, of the medical record and interviews with health professionals. From the data organized focused on the guiding question of the study, emerged the following categories: 'Gaps in the practices of health promotion'; 'Rupture of the principle of the integrality of the attention'; 'Fragility of the assistance in the scope of the professional exercise'. Thematic categories analyzed and interpreted according to the pertinent theoretical referential.

The research complied with the ethical and legal principles established in Resolution 466/12 of Health National Counsel, which guides the research involving human beings, having been approved by the Committee of Ethics in Research of the Hospital Univesitário Alcides Carneiro of the Universidade Federal de Campina Grande, under legal opinion no. 393.956.

\section{Results}

\section{Characterization of the subjects of the study}

Among the health professionals analyzed, three were female with the age ranging from 33 to 41 years and time of graduation from 10 to 18 years, three with graduation in a public institution, time of working at the family health strategy from 10 to 13 years, two with specialization courses and one attending master's degree.

On the attended updating/courses, the most prevalent were: Introduction in family health (3); Violence against women (3); Cervical cancer (3); Reproductive planning (2); Management of the Sexually Transmissible Infections/Aids (1); Epidemiological vigilance (1); pre-natal (1).

\section{Gaps in the practices of health promotion}

The education in health is considered as such while being a strategy of promotion of care, developed in the three units, individually, under the way of orientations during the appointments, however, the focus is on the user's complaint. Activities of education in health of collective character, when they are performed, were exclusively developed by the students from the Program of Education for the Work for Health: In this part of the waiting room is where the PET people stay, because I am responsible to fill in the files and everything (E1).

Dialogs of the health professionals converged with what was observed during the period of analysis. However, the activities of education in collective health performed by the students were not registered in the medical records. Although, the health professionals seized the appointments before the scheduled time, they reported that they did not provide education in collective health due to the lack of time: I didn't have this time to provide it in the waiting room with them (E1). I think that the education in health here is quite faulty for the woman; there is more individual attention than group attention (E3).

Although no collective educative activity was observed or registered in the medical record, the health professionals reported that in the past this type of activity was made, however, restricted to specific groups, such as the pre-natal appointments: [education in collective health] we do it, we deal with several subjects, among them, healthy eating habits of the pregnant woman, the pre-natal 
appointment as a whole, the examinations required in the pre-natal, the importance of having the pre-natal, increase of weight, we dealt with a lot of things concerning pre-natal, and we made contacts with other health professionals such as the nutritionist, the psychologist and it was quite interesting (E1).

The health professionals did not perceive the interrelation of the attention to the woman with strategies and programs which did not involve obstetric assistance: [education in collective health] for elderly women, specifically no, we have a group of elderly which is not specific for women, there are men and women, women are predominant, but nothing so specific for them, I see a very important participation of the women here to come and do the cytological examination, the number of elderly women who come, I think it's very interesting, they look for it. We think about doing something specifically for them in the future, concerning their sexuality (E1).

Besides the incipient incentive of the health professionals, the users do not value the educational activities and do not attend the service, a fact which was observed and proved by the statements of the health professionals: We tried to form groups of pregnant women, more than once, so that they would come, as it is scheduled, and we could have a day of educative activity and the other days of appointments, but then I couldn't gather them, because I had one, then two came, another one had one more, because actually they come on the appointment date (E2).

It is perceived that there is no participation of the users in the planning of the activities developed by the teams, also in the specification of the topics to be discussed as collective health education.

\section{Rupture of the principle of the integrality of the attention}

Activities of promotion, protection and recovering of health were contemplated by the health professionals, however, they do not imply in a complete care, once they are centered in the complaints and biological aspects restricted to the demands brought by the women, according to the following statements:

The individual [educative activities] happen according to the complaint... it will depend on what she's looking for, and not always do we approach all in one appointment (E3). [Education in health] It's also on complaints, the complete physical examination and anamneses also on the complaint (E2). We do everything to take the information in a sample manner in order to have the target reached... she goes in feeling secure to do the examination, for knowing that that is for her own sake (E1). We cover the matter of the menopause, as if she's having some treatment, if she feels the heat, if it's really symptomatic, we always ask and guide according to the age range and to the symptoms, and it's usually on the symptoms (E2).

The health professionals when questioned on which moments of attention to the woman referred the assistance to groups linked to the health programs: the pre-natal appointment, family planning, doing the clinical examination of the breasts, teaching the self-examination of the breasts, the cytological examination, the collection... hypertension and diabetes (E3).

Regarding the observation of the appointments and to the analysis of the medical records, there is convergence, partly, with the reports of the health professionals, once only individual appointments were observed, limited to the complaints and the demands brought by the women, the register of such assistance was also limited to the complaints. It is worth highlighting that the practice of data collection through the anamneses and physical examination, reported as essential in the interviews is made in an incomplete manner or not made at all by the professionals, so the reports diverge of the observations of the appointments and registers of the medical records.

\section{Fragility of the assistance in the scope of professional practice}

The nursing assistance is guided by the complaint of the woman and it is not made as a way of prevention or early detection, breaking the principles of the Unified Health System, the rights of the user and the professional legislation: We had never had the examinations, except when they come to have the cytological examination, I always ask to come and have the cytological examination made, when they have some complaint (E2). 
Health professionals recognize that the assistance rendered is different from the one that they themselves would like to receive: [requiring examinations] It's not a routine thing, I think that every woman should have the right to a breast ultrasonography and a pelvic ultrasonography annually, like we do, what I want for myself... would be very important for them too (E1).

It should be highlighted that health protection strategies, the control of diseases in health surveillance, such as the immunization of proprietary groups, except the women in the pregnancy period, and the notification of diseases by the health services was not mentioned by the professionals interviewed, neither were they observed or registered during the data collection.

It should be highlighted that the fragmentation of the assistance when the user needs to go to another professional to obtain the requirement of the examinations, is a situation which is present in several moments of the observation. The disorganization of the management of the health services, leads to the fragility of the assistance and the rupture and the actions of recovery of health, once these professionals are not allowed to prescribe medicine: I had more difficulty to prescribe medication, but we still do, but they don't want to release the medicine, this register [at the drugstore] is not approved by the Nursing Regional Counsel, the register is only made of the Medicine Regional Counsel approves, then I can prescribe, but my stamp is not valid (E1).

Still on the behavior of recovery of health, the health professionals do not know specific legislation which support their actions, choosing to transfer the responsibility by the prescription of medicine to a medical doctor: I prefer not to have problems, let her prescribe [the medical doctor], I don't prescribe, exactly because of that... the county does not guarantee that you can prescribe, so to protect myself, so I will not have any problem, I prefer (E2).

\section{Discussion}

As to the characterization of the subjects, the nursing professionals are female. A common predominance in nursing is, above all, associated to social cultural values which reveal the responsibility of care to the woman ${ }^{(13)}$. Concerning the age range and the time of graduation of the participants, they favor assistance, once younger professionals and with little professional experience are more sensitive to situations of professional stress ${ }^{(14)}$.

Considering the courses and the training courses made, the education in service has great relevant for the health professionals, once it promotes the renewal of the knowledge and simultaneously bring benefits to the health services ${ }^{(4)}$. The characteristics made evident favor the assistance based on integrality, once these professionals have experience and technical scientific knowledge which contribute for the extensive conception of the human being.

Considering the category 'Gaps in the practices of health promotion', it was observed in the nursing practices that there is a distance of actions in health focused on the identification of vulnerabilities and on the individual needs. Some professionals maintain a distorted vision on integrality, being restricted to the rendering of assistance merely having a biological and fragmented focus ${ }^{(15)}$, not considering the individual aspects which affect the women. For example, the social economic condition, the ethnic group, schooling, the sexual orientation and special needs.

It is known that the educative activities, as a strategy of health promotion, are a resource which confirms the adoption of new habits and behavior in health. This practice of construction of knowledge contributes for the autonomy of the people in their care, being necessary the exchange of knowledge and the act of creating and transforming reality, an important reference to enable the changes of the conditions of life and health ${ }^{(16)}$. Such focus is a way to develop a preventive behavior, a means to guarantee the integrality of the assistance to the woman ${ }^{(17)}$. However, the practice of the health promotion is neglected by the participant professionals.

Vertical and pathological practices predominate, which do not cover the educative practice and the 
proposal of health promotion ${ }^{(18)}$. The professionals transmit the information which they consider necessary and do not try to know the barriers which make the exercise of the autonomy in the experience of the sexual and reproductive rights difficult, for each one of the women.

Education in health is an instrument for the promotion of quality of life of the person/ family/community through the articulation of technical and popular knowledge of institutional and communitarian resources, of public and private initiatives, overcoming the biomedical paradigm of assistance to health and covering multi determinant issues of the health/disease/care process ${ }^{(19)}$.

The category 'Rupture of the principle of integrality of attention' highlights that the activities of promotion/protection and recovery of health, when performed, are guided by the biomedical paradigm. This perspective of assistance is founded on individual appointments, centered on the disease and based on complaints keeping away from the prerogatives of the Family Health Strategies ${ }^{(20)}$. Under such paradigm, the user is a mere listener, under passive condition, simply answering the questions asked by the health professionals on the health conditions. So, it is perceived that there is discontinuity and fragmentation of the action of promotion, protection and recovery of health, proprietary axes of the care in nursing and of the Family Health Strategy ${ }^{(21)}$.

It is indispensable to have the development of actions focused on the promotion, protection and recovery of health and the guarantee of implantation of public policies turned to the quality of life and the positive transformation of the determinants of the health condition ${ }^{(4)}$. It is worth highlighting that the strategies of health protection must be enhanced to all women, independently of the health condition of cycle of life and it is not restricted to groups which are inserted in health programs such as the pre-natal.
The analysis of the category 'Fragility of the assistance in the scope of the professional activities' shows that the professional practices do not consider the rights of the users, as well as the current professional legislation, thus neglecting the principle of integrality. It is recommended that the professional activities of nursing must assure the respect to the dignity and to the rights of the human being in all her vital cycle ${ }^{(21)}$.

Nursing appointment, prescription of medication and requiring examinations by nurses in the dimension of the Family Health Strategy, are attributions inserted in the innovating paradigm of attention to health, which represent a transformation of the current concept of attention to health for hundreds of years. These behaviors must be implemented in order to assure assistance in the perspective of the integral and resolute approach ${ }^{(22)}$.

Under this perspective, it is understood that the assistance of quality to the health of the woman is the one which provides the best possible welfare, from the perspective of their needs, of their human rights, of their experiences and empowerment. It also implies in the recognition of the domain on their body, sexuality, self-esteem and power of decision, facts which have been neglected in the process of construction of the identity of gender ${ }^{(23)}$. All these aspects must be understood and contemplated in the assistance of nursing.

So, it should be highlighted that, in the scenario under analysis, the existing gaps for the integral assistance to the woman are related to the noncomprehension of the process of work of the Family Health Strategy, once this assistance is permeated by the biological aspects of the users, such as the complaints, besides the fault in the ethical posture of the professionals in complying with the specific legislation, as well the principles and guidelines of the unified health system and its programs. 


\section{Conclusion}

As a principle of the Unified Health System, the integrality involves the comprehension of the woman, inserted in different contexts, from the biopsychosocial, cultural and spiritual dimensions, focused on the individual needs. For such, the actions of promotion, prevention, protection and recovery of health should be prioritized.

The analysis of the professional practices has shown that actions of promotion, protection and recovery of health are a gap in the attention to the women. The nursing assistance is centered in the individual attention focused on the complaint of the users, in detriment of the determinant aspects in the health/disease/care process, such as class, generation, ethnic group and gender, keeping away from integrality.

Considering the competences of the nurse in the context of the Family Health Strategy, it was observed that the attention to the woman does not include the actions of health developed in an articulate manner, once the woman is assisted in a fragmented manner.

As a relevant aspect, it is highlighted that the triangulation of data allowed to seize, under different perspectives, the professional practices (observation and medical records), which will not be possible with the use of the methods isolated. So, it was verified that data obtained converged, being disconnected only as to the promotion of the health and the respective lack of time for the execution of these activities. The interviews indicated the developments of action focused on education in health; however, this speech was not consolidated in the practiced observed and in the registers of the medical record. In most of the shifts observed, the activities were concluded hours before the closing of the journey of work, highlighting the availability of time for the execution of activities that involve promotion of health.

This study has as limitation the restriction of the analysis to the nursing professionals and the attention to the woman. However, it indicates the need of changes of the assistance practices in order to promote professional competences which confirm improvement in the assistance to the users, under the axis of integrality, breaking the traditional/biomedical paradigm care. For such, the investment in the initial education during graduation, and permanent education, is essential, aiming at reinforcing the competence of the nurse in the attention to the health of the woman. So, the elaboration of studies which identify and analyze strategies which contribute for the development of the ethical professional practice committed with the health of the woman is suggested.

It is expected that this study can guide actions and contribute as an element for reflection on the practice of nursing in the assistance to the health of the women.

\section{Collaborations}

Xavier AG and Santos SMP contributed for the conception, analysis, interpretation of the data, and writing of the article. Sousa FLP and Silva FL contributed for the collection, analysis and interpretation of the data. Gonçalves RL and Paixão GPN contributed for the writing of the article and final approval of the version to be published

\section{References}

1. Viegas SMF, Penna CMM. A construção da integralidade no trabalho cotidiano da equipe saúde da família. Esc Anna Nery. 2013; 17(1):13341.

2. Maia C, Guilhem D, Lucchese G. Integração entre vigilância sanitária e assistência à saúde da mulher: um estudo sobre a integralidade no SUS. Cad Saúde Pública. 2010; 26(4):682-92.

3. Pinheiro TF, Couto MT. Sexuality and reproduction: discussing gender and integral care in Primary Health Care. Physis. 2013; 23(1):73-92.

4. Ministério da Saúde (BR). Secretaria de Atenção à Saúde. Departamento de Atenção Básica. Política Nacional de Atenção Básica. Brasília: Ministério da Saúde; 2012. 
5. Ministério da Saúde (BR). Secretaria de Atenção à Saúde. Departamento de Ações Programáticas Estratégicas. Política nacional de atenção integral à saúde da mulher: princípios e diretrizes. Brasília: Ministério da Saúde; 2011.

6. Santos EI, Gomes AMT, Oliveira DC, Valois BRG, Braga RMO. Comprehensiveness in nurse's care practice in primary health care context. Rev Enferm UFPE [Internet]. 2011 [cited 2014 Aug 16]; 5(4):1054-63. Available from: http://www. revista.ufpe.br/revistaenfermagem/index.php/ revista/article/viewFile/1578/pdf_530

7. Fernandes RAQ Narchi NZ. Enfermagem e saúde da mulher. $2^{\underline{a}}$ ed. Barueri: Manole; 2013.

8. Pinto IC, Marciliano CSM, Zacharias FCM, Stina APN, Passeri IAG, Bulgarelli AF. Nursing care practices at an outpatient care center from an integrative perspective. Rev Latino-Am Enfermagem. 2012; 20(5):909-16.

9. Silva SH, Cubas MR, Fedalto MA, Silva SR, Lima TCC. Evaluative study of nursing consultation in the basic networks of Curitiba, Brazil. Rev Esc Enferm USP. 2010; 44(1):68-75.

10. Marconi MA, Lakatos EM. Fundamentos de Metodologia Científica. 7a ed. São Paulo: Atlas; 2010.

11. Duarte T. A possibilidade da investigação a 3 : reflexões sobre triangulação (metodológica). Centro de Investigação e Estudos em Sociologia [Internet]. 2009 [citado 2013 dez. 20]. Disponível em:http://www.cies.iscte.pt/destaques / documents/CIES-WP60_Duarte_003.pdf

12. Minayo MCS. O desafio do conhecimento: pesquisa qualitativa em saúde. $12^{\underline{a}}$ ed. São Paulo: Hucitec; 2012.

13. Costa FC, Borges EL, Donoso MTV. Perfil dos alunos de curso técnico de enfermagem de uma escola particular em Minas Gerais. Rev Enferm Cent Oeste Min. 2013; 3(1):554-68.

14. Gomes AR, Cruz JF, Cabanelas S. Estresse Ocupacional em Profissionais de Saúde: um estudo com enfermeiros portugueses. Psicol Teor Pesqui. 2009; 25(3):307-18.
15. Carneiro MS, Teixeira E, Silva SED, Carvalho LR, Silva BAC, Silva LFL. Dimensions of maternal health from the perspective of social representations. Rev Min Enferm. 2013; 17(2):454-61.

16. Oliveira MB, Cavalcante EGR, Oliveira DR, Leite CEA, Machado MFAS. Health education as practice of nurses in family health strategy. Rev Rene. 2013; 14(5):894-903.

17. Durand MK, Heidemann IVTSB. The promotion of women's autonomy during family health nursing consultations. Rev Esc Enferm USP. 2013; 47(2):288-95.

18. Santos SMP, Colaço EO, Silva FL, Mesquita VGF, Gonçalves RL, Araújo CRF. Concepções e práticas de profissionais de saúde sobre a violência contra a mulher. Rev Enferm UFPE [Internet]. 2014 [citado 2014 ago. 17]; 8(1):77-82. Disponível em: http://www.revista.ufpe.br/revistaenfermagem/ index.php/revista/article/view/5273/pdf_4414

19. Sousa LB, Torres CB, Pinheiro PNC, Pinheiro AKB. Práticas de educação em saúde no Brasil: a atuação da enfermagem. Rev Enferm UERJ. 2010; 18(1):55-60.

20. Paulino TSC, Guimarães J. Interfaces of the work process of nurses in the Family Health Strategy. Rev Enferm UFPE [Internet]. 2013 [cited 2014 aug 17]; 7(2):389-96. Available from: http://www. revista.ufpe.br/revistaenfermagem/index.php/ revista/article/viewArticle/2917

21. Rangel RF, Fugali MM, Backes DS, Gehlen MH, Souza MHT. Avanços e perspectivas da atuação do enfermeiro em estratégia saúde da familia. Cogitare Enferm. 2011; 16(3):498-504.

22. Borges IAL. Consulta de enfermagem, prescrição de medicamentos e solicitação de exams por enfermeiros na atenção básica à saúde. Enferm Foco. 2010; 1(1):5-8.

23. Coelho EAC, Silva CTO, Oliveira JF, Almeida MS. Integralidade do cuidado à saúde da mulher: limites da prática profissional. Esc Anna Nery. 2009; 13(1):154-60. 